\section{Wojciech Ostrowski}

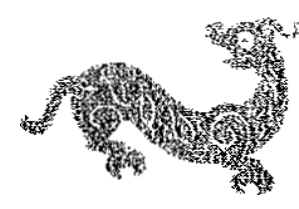

\section{WSPOMNIENIA STUDENCKIEGO DZIAŁACZA Z PLACU TIANANMEN}

Shan Tong (with Marianne Yen), Almost $\boldsymbol{a}$ revolution, The story of a Chinese Student's journey from boyhood to leadership in Tiananmen Square, The University of Michigan Press, Ann Arbor 1998, s. 344 (with a new Preface and updated Epilogue).

Pierwsze wydanie tej książki ukazało się w 1990 r. Relacja ta powstała zatem bezpośrednio po opisywanych wydarzeniach. Prawie rewolucja jest autobiografią jednego z przywódców strajku studentów chińskich z 1989 roku zawierającą opis wypadków rozgrywających się na placu Tiananmen, wydarzeń, które miały wielki wpływ na współczesną historię Chin. W świadomości wielu przedstawicieli młodego pokolenia wypadki 1989 roku są równie ważne, jak Powstania Tajpingów i Bokserów, Rewolucja Xinhai z 1911 czy Ruch 4 maja 1919 roku. Mimo że głównymi przywódcami strajku 1989 roku byli bardzo młodzi ludzie, którzy reprezentowali tylko niewielki procent wykształconej części społeczeństwa, jego znaczenie jest bezsporne.

Intencją, jaka przyświecała wydawcom książki było sprowokowanie czytelnika do odpowiedzenia sobie na pytanie: czy rozwój gospodarczy, społeczny, przestrzeganie praw człowieka i kształtowanie się państwa prawa moga zostać zapewnione w sytuacji, gdy Chinami rzadza nadal te same siły polityczne, które w przeszłości uniemożliwiały rozwój wspomnianych procesów.

Można by, oczywiście, polemizować ze stwierdzeniem, że Chinami rządzą ,te same siły polityczne" biorąc pod uwagę ogromne zmiany, jakie zaszły w po śmierci Mao w okresie reform promowanych przez Deng Xiaopinga, których efektem była wymiana elit rządzących i radykalna zmiana ideowego oblicza KPCh. I jest też faktem, iż po 1992 r. dokonało się wiele przeobrażeń dawniej nie do pomyślenia, włącznie $\mathrm{z}$ wprowadzeniem zapisu do konstytucji, iż ChRL jest państwem prawa.

Książka ta powstała po przyjeździe autora do USA. Relacjonuje w niej historię swego życia, co także jest interesujące dla czytelnika zachodniego, gdyż przedstawia realia życia codziennego Chin i zachodzących tam obecnie zmiany, jak również nadzieje i marzenia młodych Chińczyków, którzy zgodnie z opinią autora - ,jak larwa czekają aby przemienić się w piękne motyle o silnych skrzydłach".

Shen Dong urodził się w czasie „rewolucji kulturalnej". Jego imię, Dong oznacza „czerwień wschodzącego słońca", a ponieważ wchodziło ono w skład imienia Mao Zedonga, nadawano je wielu chłopcom w tamtym okresie. Pisząc autobiografię Shen wiele uwagi poświęcił dziejom swojej rodziny. Jak przystało na osobe wychowana w tradycji mandaryńskiej, nie postrzega siebie wyłącznie jako jednostkę. Na jego tożsamość składa się rodzina, i to do wielu pokoleń wstecz, jak również grupa społeczna, do jakiej przynależy. Odczuwa także swą odpowiedzialność za stan społeczeństwa i państwa.

Czytając autobiografię Shena śledzimy losy jego dziadków i ojca, który urodził się w bardzo licznej, ubogiej rodzinie. Jako mały chłopiec został on porzucony - jak to się wówczas często zdarzało i zaadoptowany przez człowieka, który bardzo pragnął mieć syna. Od dzieciństwa wpajano ojcu Shena idealistyczne wartości, które później będzie się starał przekazać synowi. Ojciec poświęcał się dla kraju niezależnie od tego, czy stawiane mu wymagania i cele były właściwe. Dokonano za niego wyboru uczelni, kierunku studiów, a także późniejszej pracy. Zostawszy filologiem języka koreańskiego (z przymusu, bo ojczyzna potrzebowała thumaczy), pracował początkowo jako nauczyciel tego jezzyka w armii, gdzie poznał matke, a od czasu ,rewolucji kulturalnej", kiedy odszedł z wojska, jako robotnik w fabryce chemicznej. Starał się wprawdzie o zmianę pracy, na taką, która byłaby zgodna z jego kwalifikacjami, choć jego pensja jako tłumacza byłaby taka sama. Dopiero po śmierci Mao, wraz z zachodzącymi zmianami, mógł wrócić do zawodu.

Matka pochodziła $\mathrm{z}$ bardzo dobrego, szlachetnego rodu $\mathrm{z}$ wielowiekowymi tradycjami. Była jednak szykanowana $\mathrm{w}$ wojsku nie tylko ze względu na pochodzenie ale też za to, że jeden $\mathrm{z}$ jej braci wyjechał na Tajwan $\mathrm{z}$ wojskami Guomindangu. Podobnie jak ojciec, podporządkowywała się ona jednak wszystkim poleceniom władz. Ponieważ podczas „rewolucji kulturalnej" potępiono elitę intelektualną, a wielu jej przedstawicieli zesłano na. „reedukację" na wieś, brakowało lekarzy w szpitalach. Będąc 
tylko pielegniarką, musiała więc pracować jako lekarz. W domu pełno więc było książek, a autor od dziecka wyrastał w środowisku „ludzi wykształconych".

Obydwaj dziadkowie Szena popełnili samobójstwo, aby „zachować twarz", gdy podczas „rewolucji kulturalnej" wyśmiewano i szydzono z nich jako „zakały społeczeństwa" i „sługusów imperializmu". Autora wychowywała babcia która starała się mu wpoić szacunek dla tradycyjnych wartości. Dzięki niej poznał starą literaturę chińską która nie była rozpowszechniana, nauczył się doceniać kulture, w rezultacie stał się, być może, bardziej wrażliwy od swoich rówieśników. Rodzice także szczególny nacisk kładli na jego wykształcenie. Mimo przeżytych cierpień, w domu panowało jednak atmosfera posłuszeństwa wobec wszystkich zarządzeń władz. Co najwyżej rodzice okazywali pewien dystans do haseł politycznych i powściągliwość, bali się także, by nie narazić się władzom.W początkowym etapie edukacji towarzyszyła Shenowi intensywna indoktrynacja polityczna, która czesto stawiano na pierwszym miejscu przed właściwą edukacją. Czasem lekcje były całkowicie poświęcone wspaniałości Armii Ludowej, rządu i otoczonego uwielbieniem Mao. Mały chłopiec całkowicie bezkrytycznie akceptował wszystkie slogany i hasła propagandowe. Nie był jednak na tyle posłuszny i zdyscyplinowany, aby zostać od razu przyjętym do organizacji pionierskiej mimo dobrych wyników szkolnych. Było to dla niego wówczas bardzo ważne 1 musiał się bardzo starać, aby otrzymać wymarzoną odznakę. Shen nie był idealnym dzieckiem. Gdy jego ojciec otrzymał pracę jako tłumacz w Korei, kradł znaczki, ponieważ sprzedawcy bardzo oszukiwali na cenach

W bardzo interesujący sposób relacjonuje wydarzenia burzliwych lat siedemdziesiątych, tak jak widział je jako chłopiec: śmierć premiera Zhou Enlaia, masowe, wielodniowe protesty na Placu Tiananmen wiosna 1976 r., śmierć Mao, Mur Demokracji z 1978 r. itd. Opisy te są tym ciekawsze, gdyż relacjonuje on reakcje i wrażenia ludzi oraz rysuje sceny, trudne nawet do wyobrażenia obserwatorowi zachodniemu. Gdy prezydent Nixon odwiedził Pekin w 1972 r. i zapanowała wielka ekscytacja ta wizyta, pierwsza po latach konfrontacji i potępiania USA, jako dziecko zapytał sąsiada: „czyż Amerykanie nie są naszymi wrogami?". Usłyszał wtedy: „Diabły amerykańskie poddały się... i znowu chca zostać naszymi przyjaciółmi". Gdy nie długo później przyjechał z wizytą premier japoński Tanaka, autor z kilkoma innymi szkrabami pobiegli po swoje karabiny-zabawki i pomaszerowali w kierunku trasy jego przejazdu, by „walczyć z Japończykami", i był bardzo zdumiony, gdy ich zatrzymano i zaczęto tłumaczyć, że teraz Japończycy są przyjaciółmi. Jak wspomina autor, kiedy zmarł Mao, ludzie byli znacznie mniej przejęci, niż wcześniej po zgonie cieszącego się gorącą sympatią premiera Zhou. Jednak jak on odnotowuje, ludzie nie mogli sobie wyobrazić Chin bez Przewodniczącego Mao. Jedna z koleżanek jego siostry powiedziała nawet: ,powrócimy teraz do 'starego społeczeństwa' i prawdopodobnie nie będziemy już mogły chodzić do szkoły... będziemy musiały zostać dziećmi-robotnikami i pracować, na przykład, u fryzjera". Jednak życie nie potwierdziło tych obaw.

Czasy studenckie to dla autora okres wolności i swobody. Pierwsze lata studiów poświęcał całkowicie nauce. Chętnie uczęszczał na zajęcia i z zapałem chłonął wiedzę. Późniejsze lata, to czas poszukiwań, stawiania nieortodoksyjnych pytań i zwątpienia w partię.

W czasie, gdy Chiny przechodzą gruntowne reformy ekonomiczne, zainicjowane przez Deng Xiaopinga, Szen próbuje odnaleźć się w nowej rzeczywistości. Handluje, na przykład, kremem na porost włosów, podobnie jak czyniła to większość jego uniwersyteckich kolegów. Zarabia - jak na studenta — bardzo dobrze, jednak to nie przynosi mu satysfakcji. W roku 1988 głównie pod wpływem kolegów - włączył się w działalność Zrzeszenia Studentów Uniwersytetu Pekińskiego, zbierając fundusze, organizując pokazy mody. Zajmował się również kontaktami ze studentami z innych rejonów.

Przełomem w życiu Shena było związanie się w 1988 r. z Komitetem Akcji, organizacją broniąca praw człowieka. Powstał on na uniwersytecie w związku z zabiciem przez kilku chuliganów jednego ze studentów i żądaniami ich surowego ukarania. Choć to nastąpiło i sąd wydał wysokie wyroki, wypadek ten sprowokowal dyskusje o wiele bardziej fundamentalne o sytuacji w Chinach. Niestety, nie wiele on osiągnął, gdyż władze uczelni nakazały jego rozwiązanie. Członkowie Komitetu byli wcześniej śledzeni, straszeni, a kilku z nich, po rozwiązaniu Komitetu, zmuszono do napisania samokrytyki. Nie były to, jak widać, zbyt dotkliwe represje, i nie mogły one odstraszyć od podejmowania innych działań. Przykrym skutkiem dla autora była niemożność złożenia na czas odpowiednich dokumentów, aby wyjechać do Stanów Zjednoczonych na studia — tak jak to czyniło wielu spośród jego kolegów, gdyż zbyt dużo czasu poświęcił na tę działalność, a następnie na pisanie samokrytyki.

Na początku 1989 r. organizował on „Instytut Olimpijski", w którym wraz ze swoimi kolegami prowadził naukowe dyskusje, prelekcje i spotkania ze znanymi osobistościami. Pod wpływem temperamentu Shena Instytut zmienił swój profil. Stał sie bardziej upolityczniony. Było to również ściśle związane $\mathrm{z}$ niezadowoleniem narastajacym wśród studentów. Wraz z nowo poznanymi studentami założył on „Salon Demokracji", jaki wprost chciał wpływać na politykę władz przez wywieszanie dazibao — komunikatów studenckiego radia oraz wydawanie gazetki.

Dalszą część książki stanowi szczegółowy opis rozwoju ruchu studenckiego i towarzyszących mu wydarzeń, rozprzestrzeniania się akcji na inne 
szkoły, eskalacji żądań studentów, wreszcie samego protestu na Placu Tiananmen oraz jego zdławienia. W tym końcowym etapie autor staje się bardziej zaangażowanym obserwatorem, niż protagonistą wydarzeń. Dramatycznej nocy nie jest obecny na Placu, a tylko stara się tam dotrzeć. Opisuje więc sceny walk ulicznych, których był świadkiem, i w jakich padło wiele ofiar. Ulega jednak łatwo namowom rodziny, która sprowadza go do domu i ukrywa. Daje on zatem bardzo wiarygodny i nader szczegółowy opis tych wydarzeń oraz ruchów, z jakich wyrósł protest studencki. Opis życia i działalności Shen Tonga kończy się w momencie jego ucieczki do Stanów Zjednoczonych.

Książka rysuje bardzo interesujący obraz Chin, pisany z perspektywy osoby będącej uczestnikiem i naocznym świadkiem wydarzeń, jak również przemian zachodzących w tym kraju w ciągu ostatniego dwudziestolecia. Mówi ona wiele o procesach formowania się społeczeństwa obywatelskiego, codziennym życiu, wartościach, poglądach, sposobie pojmowania świata i przeżyciach ludzi wychowanych w epoce Mao i po niej. Czytając ją możemy ujrzeć dramatyczne wydarzenia 1989 r. z perspektywy ich uczestnika, poznając jego sposób myślenia i dążenia, jak też poznać drogę, która doprowadziła go na plac Tiananmen. 